\title{
VOTER PHOTO ID LAWS: USING PRIMARY SOURCE ELECTION TURNOUT DATA AND FOREIGN EXAMPLES TO IDENTIFY THE PROPER MECHANISMS FOR IMPLEMENTATION
}

\author{
Mallory Wilson \\ I. INTRODUCTION
}

The Need for Voter ID Laws

The United States Constitution authorizes Congress to establish the time and manner for electing Senators and Representatives, ${ }^{1}$ "[b]ut States have broad powers to determine the conditions under which the right of suffrage may be exercised." ${ }^{2}$ Specifically, "[e]ach State has the power to prescribe the qualifications of its officers and the manner in which they shall be chosen." 3 Further, "the Tenth Amendment reserves to the States all powers not specifically granted to the Federal Government, including 'the power to regulate elections." " 4 It then follows that these principles allow states to decide whether to implement laws requiring voters to show identification when they vote.

The leading case in this area is Crawford v. Marion County Board of Elections. ${ }^{5}$ In this case, the United States Supreme Court upheld Indiana's voter photo ID law. ${ }^{6}$ By upholding the law, the Supreme Court made the concept of voter photo ID laws constitutionally permissible. ${ }^{7}$ While the concept of the voter photo ID laws has been validated, many of these laws continue to be challenged based on the mechanisms by which they are implemented.

In a republican system of government, the only way the people can trust their government and the laws enacted by it is to have confidence that public officials were properly elected. Enacted laws that verify the identity of a voter provide one of the strongest ways to ensure only eligible citizens vote and vote only once. Data on in-person voter fraud is sparse because this type of fraud is easy to commit but difficult to spot. ${ }^{8}$ However, a study by the non-

\footnotetext{
${ }^{1}$ U.S. Const. art. I, § 4, cl. 1.

${ }^{2}$ Id.

${ }^{3}$ Shelby Cnty. v. Holder, 133 S. Ct. 2612, 2623 (2013).

${ }^{4}$ Id. at 2616.

${ }^{5}$ Crawford v. Marion Cnty. Election Bd., 553 U.S. 181 (2008).

${ }^{6}$ Id.

${ }^{7} \mathrm{Id}$.

8 John Fund \& Hans von Spakovsky, Column: Underestimating Our Voter Fraud Vulnerability, USA TODAY (Oct. 21, 2012, 5:44 PM), http://www.usatoday.com/story/ opinion/2012/10/21/voter-fraud-voter-id/1647913/.
} 
partisan Pew Center on the States found that there are more than twenty-four million voter-registration records in the United States and that about one eighth "are inaccurate, out-of-date or duplicates."” Specifically, “[n]early 2.8 million people are registered in two or more states, and perhaps 1.8 million registered voters are dead.” 10 These inaccuracies and duplications provide opportunities for various forms of voter irregularities.

Even though it is difficult to detect the full extent of voter fraud, many examples have in fact been documented. In Iowa, three citizens were arrested for voting illegally in both the 2010 and 2011 elections. ${ }^{11}$ A study done in 2004 by the New York Daily News found 46,000 people were dually registered in Florida and New York and that somewhere between 400 and 1000 of those people voted in both elections. ${ }^{12}$ Because "Florida decided the 2000 presidential election by 537 votes," ${ }^{13}$ it is easy to see how different the result of that election could have been if mechanisms had been in place to prevent people from improperly voting by voting multiple times or voting in inappropriate locations. It is also not hard to imagine how many other elections could have been similarly impacted by cases of in-person voter fraud that occurred but were never caught. It is imperative to the integrity of government that all types of voter fraud be prevented. The best way to stop voter fraud is to require every voter to prove his or her identity before voting.

Voter photo identification (voter ID) laws are needed to protect the integrity of elections. As noted above, protecting the integrity of elections protects the integrity of the government and the laws that it promulgates. If there is integrity in the voting system, people will have confidence in their elected officials and will, therefore, have more confidence in, and respect for, the government and the laws implemented by that government. The reverse is also true. The less confidence people have in the election process, the less confidence they will have in, and the less respect they will have for, their elected officials and enacted laws. For the 2012 General Election in Indiana, there were 4,555,257 registered voters. ${ }^{14}$ Of those 4.5 million voters, 2,072,974 citizens voted in person. ${ }^{15}$ If even one percent of those voters cast an illegal ballot, over 20,000 illegal votes would have been cast. Twenty thousand illegal votes could easily affect the outcome of an election and put

\footnotetext{
${ }^{9}$ Id.

${ }^{10}$ Gregory Korte, Pew Study: 1 in 8 Voter Records Flawed, USA TodAy (Feb. 14, 2012, 6:28 AM), http://usatoday30.usatoday.com/news/politics/story/2012-02-10/pew-studyinaccurate-voter-registration-rolls/53083406/1.

${ }^{11}$ Fund \& von Spakovsky, supra note 8.

${ }^{12} I d$.

${ }^{13} \mathrm{Id}$.

${ }^{14}$ Voter Registration and Turnout Statistics, INDIANA ELECTION Division, http://www.in.gov /sos/elections/2983.htm (last visited Oct. 13, 2013).

${ }^{15} \mathrm{Id}$. Voters also voted absentee. Since this paper concerns voter photo ID laws which combat fraud against in-person voting, this paper will not discuss absentee voting.
} 
a wrongfully elected candidate into office.

In the United States, a photo ID is needed for many purposes. A photo ID is commonplace in our society and is widely accepted as a beneficial and effective means for ensuring that laws and rules are properly implemented. A person is not able to obtain a passport, ${ }^{16}$ board a plane, ${ }^{17}$ purchase alcohol, ${ }^{18}$ apply for Social Security, ${ }^{19}$ open a bank account, ${ }^{20}$ obtain certain non-prescription medicines from behind the pharmacy counter, ${ }^{21}$ get a library card, ${ }^{22}$ or ship an item with UPS ${ }^{23}$ without a photo ID. It is similarly logical to require a person to verify his or her identity prior to engaging in the more important act of helping select the people who will have the power to determine the laws of our states and country.

This Note will argue that voter photo ID laws are necessary to combat in-person voter fraud, thereby helping to ensure the integrity of the election system. The objections to imposing voter photo ID laws are well-known. These objections, which are considered below, essentially assert that voter photo ID laws impose an undue burden on the right to vote. It is important to note from the outset that the law does not forbid all burdens, only those that are undue. Burdens are permitted if the legitimate state interest they promote outweighs the impact on voter participation in elections. Therefore, a balancing of interests is needed. This Note will demonstrate that the benefits afforded by these laws outweigh all of their costs. This Note will use primary source election data and will draw on the experiences of several states and several foreign countries to support the expanded acceptance of these laws. This note will also identify ways that voter photo ID laws benefit society by promoting social involvement and by recognizing the existence of social duties, similar to participation in the jury system. The United States Supreme Court has already considered and approved the concept of voter photo ID laws. ${ }^{24}$ However, this Note is needed for several reasons. First, not every state

${ }^{16}$ First Time Applicants, U.S. PASSPORT \& InTERnATIONAL TRAveL, http://travel.state.gov/ content/passports/english/passports/first-time.html (last visited Feb. 12, 2014).

${ }^{17}$ Acceptable IDs, TrANSPORTATION SECURITY ADMINISTRATION, http://www.tsa.gov/ traveler-information/acceptable-ids (last visited Feb. 12, 2014).

18 Alcohol Laws, InDianA STATE EXCISE POLICE, http://www.in.gov/atc/isep/2384.htm (last visited Feb. 12, 2014).

${ }^{19}$ Ashe Schow, 24 Things That Require a Photo ID, WASHington ExAminER, http:// washingtonexaminer.com/article/2534254\#.UgvM3Dkd6ZM.twitter (last updated Aug. 14, 2013).

${ }^{20}$ Acceptable Forms of Identification, COMMERCE BANK, http://www.commercebank.com/ personal/studentservices/banking/international/identification.asp (last visited Feb. 12, 2014).

${ }^{21}$ Over the Counter Medications, DRUGS.COM, http://www.drugs.com/otc/ (last visited Feb. 12, 2014).

${ }^{22}$ Getting a Library Card, THE INDIANAPOLIS PUBLIC LIBRARY, http://www.imcpl.org/using/ card/ (last visited Feb. 12, 2014).

${ }^{23}$ Photo ID Requirements at Retail Shipping Locations, UPS, http://www.ups.com/content/ us/en/about/news/service_updates/retail_requirement.html (last visited Feb. 12, 2014).

${ }^{24}$ Crawford v. Marion Cnty. Election Bd., 553 U.S. 181. 
has enacted voter photo ID laws. Such states can use the arguments in this Note to supplement efforts to pass appropriate laws. Second, both those states that have enacted voter photo ID laws and those states that are considering them can use the reasoning of this Note to defend against likely challenges from opponents. Third, at least some opponents should be persuaded to support voter photo ID laws because such laws are commonplace in countries around the world, including countries often cited as international role models by people and groups who oppose voter photo ID laws.

To date, voter photo ID laws have been enacted in thirty-four states in the United States and in several democratic countries around the world. This Note will look at the voter photo ID systems of Georgia, Indiana, Kansas, and Tennessee and at the systems implemented in Brazil, Canada, the Republic of China (Taiwan), and three countries in the European Union. The domestic examples will demonstrate how a voter photo ID law implemented with the proper mechanics is constitutionally permissible. The international examples will highlight how the concept of voter photo ID laws is widely accepted in many democratic countries precisely because they help ensure the integrity of elections.

Finally, this Note will argue that while the very strict voter ID laws enacted in other countries work well for them, the less intrusive voter photo ID laws as enacted in Georgia, Indiana, Kansas, and Tennessee provide the best model for the United States, given our federalist system of government in which states control conditions under which elections are conducted. Voter photo ID laws have been discussed in many articles and papers, expressing both support ${ }^{25}$ and opposition. ${ }^{26}$ This Note will demonstrate that voter photo ID laws are needed to prevent voter fraud, and that identification laws are widely accepted by governments and their citizens. Voter photo ID laws have become the norm in many democratic countries around the world, including many countries in the European Union.

\section{VOTER PHOTO ID LAWS ENACTED IN THE UNITED STATES}

To date, thirty-four states have some type of identification requirement

\footnotetext{
${ }^{25}$ See, e.g., The Good Sense of Voter ID, NATIONAL ReVIEw OnLine, http://www.national review.com/article/355827/good-sense-voter-id-editors (last updated Aug. 15, 2013); Editorial: No Reason Not to Support Voter ID Laws, TusCaloosa News, http://www. tuscaloosanews.com/article/20130503/NEWS/130509957 (last updated May 2, 2013).

${ }^{26}$ See, e.g., Cynthia Tucker, Voter ID Laws Have Just One Purpose - disenfranchisement, PATRIOT NEws, http://www.pennlive.com/opinion/index.ssf/2013/10/voterid_laws_have_just _one_purpose_-_and_its_not_good_cynthia_tucker.html (last updated Oct. 29, 2013); The Dishonesty of Voter ID Laws, THE NEw YoRK TIMEs OPINION PAGES, http://www.nytimes .com/2013/10/01/opinion/the-dishonesty-of-voter-id-laws.html?_r=0 (last updated Sept. 30, 2013).
} 
for voters, ${ }^{27}$ although not all of these laws are in full force as enacted, either because the laws have not yet gone into effect or because of challenges to the mechanisms by which these laws are to be implemented. ${ }^{28}$ The states of Arkansas, North Carolina, and Wisconsin each have passed legislation for voter photo ID laws; but these laws have not yet gone into effect. ${ }^{29}$ The voter photo ID law in Pennsylvania has been invalidated by that state's Supreme Court. ${ }^{30}$ In that case, the invalidation arose from deficient implementation mechanisms, not from a categorical rejection of the concept of voter photo ID laws.

There are two main categories of voter ID laws-strict vs. non-strict and photo vs. non-photo. ${ }^{31} \mathrm{~A}$ law is considered a photo ID law if the voter is required to present an ID containing a photograph of the voter. ${ }^{32}$ Non-strict non-photo ID laws require a voter to present some form of identification but do not require a photograph. ${ }^{33}$ Non-strict photo ID laws give a voter other options for casting a regular ballot. ${ }^{34}$ Strict photo ID laws require a voter to present a photo ID. ${ }^{35}$ If he or she is unable to do so, he or she may vote using a provisional ballot but must later return to present some form of identification. ${ }^{36}$ This paper will consider one type of voter identification law-the strict photo identification law. Non-strict and non-photo identification laws are outside the scope of this Note, which reduces the number of relevant states. Eight states currently have strict photo ID laws in effect, but this Note will consider four: Georgia, Indiana, Kansas, and Tennessee. ${ }^{37}$

27 Voter Identification Requirements, National Conference of State Legislatures, http://www.ncsl.org/legislatures-elections/elections/voter-id.aspx (last updated Mar. 23, 2015).

${ }^{28} I d$.

${ }^{29}$ Id.

30 Ari Berman, Pennsylvania Ruling Shows the Problem with Voter ID Laws, THE NATION, http://www.thenation.com/blog/177976/pennsylvania-ruling-shows-problem-voter-id-laws\# (last updated Jan. 17, 2014).

31 NATiOnAl Conference OF StATE Legislatures, supra note 27.

${ }^{32} I d$.

${ }^{33} I d$.

${ }^{34} I d$.

${ }^{35} I d$.

${ }^{36}$ Voting Methods and Options, U.S. Vote Foundation. https://www.usvotefoundation.org/ state-elections/state-voting-laws-requirements (last visited Oct. 22, 2013). Many of these nonstrict, non-photo ID states, such as Arizona and Alabama, allow the use of utility bills or bank statements as proof of identity. National Conference of State Legislatures, supra note 27. These non-strict and non-photo ID laws are not discussed in this paper, as they do not help prevent voter fraud. Under either of these systems, a voter can ultimately cast a ballot using someone else's name and utility bill without having to verify their identity.

${ }^{37}$ National Conference of State Legislatures, supra note 27. The other four states with strict photo ID laws are Mississippi, Texas, Virginia, and Wisconsin. The statutes in Mississippi, Virginia, and Wisconsin will not be evaluated in this paper since they have only recently gone 


\section{A. Georgia}

Georgia, along with Indiana, was one of the first states to implement voter photo ID requirements, with its law going into effect in $2005 .{ }^{38}$ The Official Code of Georgia Annotated § 21-2-417 outlines the specific requirements of Georgia's law. It provides that "each elector shall present proper identification to a poll worker at or prior to completion of a voter's certificate at any polling place and prior to such person's admission to the enclosed space at such polling place." ${ }^{39}$ Any of the following types of identification may be used for voting purposes: a "Georgia's driver's license," a "valid Georgia voter identification card . . . or other valid identification card" 40 that was issued by the State of Georgia or the United States if it contains a photograph, a United States passport, an employee ID card issued by the United States government or the State of Georgia, a United States military ID containing a picture, or a tribal identification card with a picture. $^{41}$

There is abundant case law in Georgia resulting from attempts to strike down its voter photo ID law. In Common Cause v. Billups, ${ }^{42}$ a group of registered voters, along with nonprofit organizations, brought suit against the state in federal court claiming the state's voter photo ID law violated the Fourteenth and Twenty-Fourth Amendments to the United States Constitution, the Civil Rights Act of 1964, and Section Two of the Voting Rights Act by placing an undue burden on the right to vote. ${ }^{43}$ The United States District Court for the Northern District of Georgia dismissed the complaint for lack of standing and denied the plaintiff's request for an injunction. ${ }^{44}$ On appeal, the Eleventh Circuit Court of Appeals held that the voters had standing to challenge the law but affirmed the denial of the injunction and upheld the photo ID requirement. ${ }^{45}$ The court found that "the Photo ID requirement does not unduly burden the right to vote," 46 and concluded that the "insignificant burden imposed by the Georgia statute is

into effect and there is not yet adequate data to analyze. Texas' voter photo ID law went into effect after the Supreme Court struck down the preclearance requirement of the Voting Rights Act. Texas' law will not be discussed in this paper as their first election with the requirement was in November 2013. Rick Jervis, New Voter ID Law Tested During Texas Elections, USA TODAY, http://www.usatoday.com/story/news/nation/2013/11/05/

texas-voter-id-law-elections/3436047/ (last updated Nov. 5, 2013).

38 NATIONAL CONFERENCE OF STATE LEgISLATURES, supra note 27.

39 GA. CODE ANN. § 21-2-417 (2012).

${ }^{40} I d$.

${ }^{41} \mathrm{Id}$.

${ }^{42}$ Common Cause v. Billups, 504 F.Supp.2d 1333 (N.D. Ga. 2007).

${ }^{43} \mathrm{Id}$.

${ }^{44} \mathrm{Id}$.

${ }^{45}$ Common Cause v. Billups, 554 F.3d 1340 (11th Cir. 2009).

${ }^{46}$ Id. at 1354 . 
outweighed by the interests in detecting and deterring voter fraud." 47

While this case was pending in federal court, the Democratic Party of Georgia filed suit in state court against the state of Georgia alleging the voter photo ID law violated the Equal Protection Clause of the state constitution and sought to bar its implementation. ${ }^{48}$ The trial court granted summary judgment in favor of the state, and the Georgia Supreme Court affirmed the trial court's ruling. ${ }^{49}$ The Georgia Supreme Court found "the photo ID requirement as implemented in the 2006 Act to be a minimal, reasonable, and nondiscriminatory restriction which is warranted by the important regulatory interests of preventing voter fraud." 50

After Georgia's law went into effect, both opponents and supporters made predictions. Opponents claimed that the law would suppress the vote of minorities; supporters argued that the law would combat fraud. ${ }^{51}$ The Atlanta Journal-Constitution (AJC) reviewed voting patterns across the state for the first five years the law was in effect. ${ }^{52}$ After analyzing election data, the AJC found that voter participation from 2006, the latest election year before the law was implemented, to 2010 actually rose by forty-four percent. For the same time period, the AJC concluded that Hispanic voter participation rose by sixty percent. ${ }^{53}$ However, opponents continue to oppose Georgia's law because they contend that accurate data about the impact of the voter photo ID laws cannot be determined until more time has passed and more election data can be obtained. ${ }^{54}$ That claim is unpersuasive for at least two reasons. First, five years of voter conduct provides a substantial amount of data. Second, if data from subsequent elections establishes a contrary result that can be attributed to Georgia's voter photo ID law, as opposed to some other cause for a reduction in voter participation rates, opponents can use that data to support new challenges. Remedial relief in light of real experience is preferable over injunctive relief based on speculation that adverse data might someday be found.

\section{B. Indiana}

Like Georgia, Indiana was one of the first states to pass a voter photo ID law. Indiana Code $\S 3-5-2-40.5$ outlines the identification requirements

\footnotetext{
${ }^{47} I d$.

${ }^{48}$ Democratic Party of Georgia v. Perdue, 288 Ga. 720 (2011).

${ }^{49} \mathrm{Id}$.

${ }^{50} \mathrm{Id}$. at 730.

51 Shannon McCaffrey, Despite Voter ID law, Minority Turnout Up in Georgia, AJC.COM, www.ajc.com/news/news/despite-voter-id-law-minority-turnout-up-in-georgi/nR2bx/ (last updated Sept. 3, 2012).

${ }^{52}$ Id.

${ }^{53}$ Id.

${ }^{54}$ Id.
} 
for voting. A document satisfies the photo ID requirements if it meets all of the following criteria:

(1) The document shows the name of the individual to whom the document was issued, and the name conforms to the name in the individual's voter registration record.

(2) The document shows a photograph of the individual to whom the document was issued.

(3) The document includes an expiration date, and the document:

(A) is not expired; or

(B) expired after the date of the most recent general election.

(4) The document was issued by the United States or the state of Indiana. ${ }^{55}$

If the document was issued by the United States Department of Defense, a branch of the uniformed services, the Merchant Marine, or the Indiana National Guard and meets all of the other requirements, it does not need to have an expiration date or it may have an indefinite expiration date. ${ }^{56}$

In addition to the broad scope of legally recognized documents, there are also exceptions to the requirements of this law. If a person resides in a state-licensed care facility that is also the location of the precinct polling place, the voter does not need to show identification. ${ }^{57}$ In addition, if a voter is unable to show identification, the precinct election board may challenge the voter. ${ }^{58}$ However, in this situation, the voter may still cast a provisional ballot. $^{59}$

Almost as soon as Indiana's voter photo ID law was passed, a lawsuit was filed challenging its requirements. In Indiana Democratic Party v. Todd Rokita, ${ }^{60}$ several groups, including the Indiana Democratic Party, the Marion

\footnotetext{
${ }^{55}$ IND. CODE § 3-5-2-40.5(a) (2011).

${ }^{56}$ IND. CODE § 3-5-2-40.5(b) (2011).

${ }^{57}$ IND. CODE § 3-11-8-25.1(e) (2013).

58 IND. CODE § 3-11-8-25.1(c) (2013).

${ }^{59} \mathrm{Id}$. Opponents have argued that this ability to cast a provisional ballot is not an effective method to allow voters without a photo ID to vote. "The count rate for identification-related ballots in Indiana is very low-about $80 \%$ of identification-related provisional ballots do not get counted.” Michael J. Pitts, Photo ID, Provisional Balloting, and Indiana's 2012 Primary Election, 47 U. of RichmOND L. REV. 939, 955 (2013). However, this does not prove that voter photo ID laws disenfranchise people without an ID. This is an added burden to the right to vote. It is just highly probable that people who cast a provisional ballot at their polling location were too lazy, didn't care enough about voting, or simply forgot to go to the county election office within ten days. However, this "burden" of requiring people to return to the county election office is outweighed by the benefits of a stronger, more secure voting system.

${ }^{60}$ Indiana Democratic Party v. Rokita, 458 F.Supp.2d 775 (S.D. Ind. 2006).
} 
County Democratic Central Committee, Democratic state representatives and non-profit organizations, jointly brought an action against the Marion County Board of Elections, the Indiana Secretary of State, and the Election Division Directors to challenge Indiana's voter photo ID law. ${ }^{61}$ The plaintiffs alleged that Indiana's law violated the First and Fourteenth Amendments to the U.S. Constitution by placing a substantial burden on the right to vote. ${ }^{62}$ The case was heard in the United States District Court for the Southern District of Indiana, and Judge Sarah Evans Barker granted the State of Indiana's motion to dismiss. ${ }^{63}$ Judge Barker found that the petitioners had "not introduced evidence of a single, individual Indiana resident who will be unable to vote as a result of SEA 483 or who will have his or her right to vote unduly burdened by its requirements." ${ }^{4}$ The voter photo ID law was upheld by the Seventh Circuit U.S. Court of Appeals, ${ }^{65}$ which found that the

purpose of the Indiana law is to reduce voting fraud, and voting fraud impairs the right of legitimate voters to vote by diluting their votes-dilution being recognized to be an impairment of the right to vote. On one side of the balance in this case is the effect of requiring a photo ID in inducing eligible voters to disfranchise themselves. That effect . . . is slight. ${ }^{66}$

With this insight, the Seventh Circuit brought a new perspective to the undue burden argument. Instead of burden being considered only in terms of a voter photo ID law's impact on opponents, the court's point about vote dilution adds a new consideration. The "balance" no longer involves two elements-claimed disenfranchisement because of burden versus claimed benefit combined with burden mitigation. Now, preventing dilution of the vote of legitimate voter, itself a form of impairment of the right to vote, should be taken into consideration when balancing the asserted interests.

Opponents of Indiana's law appealed the decisions of the District Court and the Court of Appeals to the United States Supreme Court. ${ }^{67}$ The Supreme Court upheld the lower courts' rulings and concluded:

[T]he universally applicable requirements of Indiana's voteridentification law are eminently reasonable. The burden of acquiring, possessing, and showing a free photo

\footnotetext{
${ }^{61} \mathrm{Id}$.

${ }^{62} I d$.

${ }^{63} \mathrm{Id}$.

${ }^{64} \mathrm{Id}$. at 783 .

${ }^{65}$ Crawford v. Marion Cnty. Election Bd., 472 F.3d 949 (7th Cir. 2007).

${ }^{66} \mathrm{Id}$. at 952.

${ }^{67}$ Crawford v. Marion Cnty. Election Bd., 553 U.S. 181.
} 
identification is simply not severe, because it does not even represent a significant increase over the usual burdens of voting. And the State's interests are sufficient to sustain that minimal burden. That should end the matter. That the State accommodates some voters by permitting (not requiring) the casting of absentee or provisional ballots, is an indulgencenot a constitutional imperative that falls short of what is required. ${ }^{68}$

Through the Crawford decision, the United States Supreme Court has established the principle that voter photo ID laws are, as a concept, constitutionally permissible.

After the law was upheld, people of nearly every political philosophy began expressing their views. Many articles expressed fears and opposition to the law. ${ }^{69}$ It has even been claimed that Judge Posner, a member of the Seventh Circuit Court of Appeals and the author of the Seventh Circuit decision upholding the law, "disavowed" his support for the law and for the judicial reasoning used to uphold it. The New York Times published an article citing a statement Judge Posner made in his book Reflections on Judging. ${ }^{70}$ In this article, the New York Times claims that Judge Posner admitted to being wrong when he supported the voter photo ID law and wrote the majority opinion upholding Indiana's voter photo ID law. ${ }^{71}$ However, Judge Posner recently debunked that claim, stating that the only source of his alleged recanting was a single sentence in his book, a sentence that had been misunderstood and taken out of context. ${ }^{72}$ Judge Posner explains:

I did not say that my decision, and the Supreme Court's decision affirming it (written, be it noted, by the notably liberal Justice Stevens), were wrong, only that, in common with many other judges, I could not be confident that it was right, since I am one of the judges who doesn't understand the electoral process sufficiently well to be able to gauge the

${ }^{68}$ Id. at 209. (internal citations omitted) (emphasis added).

${ }^{69}$ See, e.g., Editorial: A Transparent Effort, JouRnAL SENTINEL, http://www.jsonline.com/ news/opinion/29535689.html (last updated Jan. 9, 2008); Voter ID Law Turns Away Nuns, students, CONCORD MONITOR, http://www.concordmonitor.com/article/voter-id-law-turnsaway-nuns-students (last updated May 7, 2008).

${ }^{70}$ John Schwartz, Judge in Landmark Case Disavows Support for Voter ID, THE NEW YoRK TIMES, http://www.nytimes.com/2013/10/16/us/politics/judge-in-landmark-case-disavowssupport-for-voter-id.html?_r=0 (last updated Oct. 15, 2013).

${ }^{71}$ Id.

72 Richard A. Posner, I Did Not 'Recant' on Voter Id Laws, New RePUBLIC, http://www.new republic.com/article/115363/richard-posner-i-did-not-recant-my-opinion-voter-id (last updated Oct. 27, 2013). 
consequences of decisions dealing with that process. ${ }^{73}$

Judge Posner's comments express a healthy (and refreshing) recognition of the limitations of judges with regard to the substitution of their conclusions for the decisions of a more numerous body of legislators elected by the people. Also inherent in Judge Posner's statement is recognition of the different natures of judicial and legislative competence. Unlike the "cases and controversies" limitations on courts, ${ }^{74}$ legislatures are able to listen to the positions of a wide variety of interested persons and groups and are able to consider an issue's relationship to other laws and social policies. ${ }^{75}$ Ultimately, the law governing the validity of Indiana's voter photo ID laws is clear and unmistakable. All three levels of the federal courts that considered the matter, culminating in a six to three decision by the United States Supreme Court, have concluded that the law is constitutional and does not unduly burden the right to vote of any class of voters." ${ }^{, 6}$ This analysis and this conclusion, of course, apply equally to all other states.

\section{Kansas}

Soon after the Indiana and Georgia laws were upheld, Kansas enacted a similar strict voter photo ID law. Kansas Statute Annotated § 25-2908 details the identification requirements that a voter must meet in order to cast a ballot. The law requires a voter to present the following to the election board: the voter's name, the voter's address, if required, the voter's signature, and a valid form of identification. ${ }^{77}$ Acceptable forms of identification are outlined in subsection (h), which provides:

(1) The following forms of identification shall be valid if the identification contains the name and photograph of the voter and has not expired. Expired documents shall be valid if the bearer of the document is 65 years of age or older:

(A) a driver's license issued by Kansas or by another state or district of the United States;

(B) a state identification card issued by Kansas or by another state or district of the United States;

(C) a concealed carry of handgun license issued by Kansas

${ }^{73} \mathrm{Id}$.

${ }^{74}$ U.S. Const. art. III, § 2, cl. 1.

75 The Legislative Branch, THE WHITE House, http://www.whitehouse.gov/our-government/ legislative-branch (last visited Feb. 11, 2014).

76 John Fund, Winning the Fight for Voter-ID, NATIONAL REVIEw OnLINE, http://www. nationalreview.com/article/368864/winning-fight-voter-id-john-fund (last updated Jan. 19, 2014).

${ }^{77}$ KAN. STAT. ANN. § 25-2908 (2012). 
or a concealed carry of handgun or weapon license issued by another state or district of the United States;

(D) a United States passport;

(E) an employee badge or identification document issued by a municipal, county, state, or federal government office or agency;

(F) a military identification document issued by the United States;

(G) a student identification card issued by an accredited postsecondary institution of education in the state of Kansas;

(H) a public assistance identification card issued by a municipal, county, state, or federal government office or agency; or

(I) an identification card issued by an Indian tribe. ${ }^{78}$

Similar to other states' laws, Kansas' voter photo ID law includes a provision that permits a voter to cast a provisional ballot if that person is unable to present a form of identification required by subsection (h). ${ }^{79}$

As in Indiana and Georgia, a lawsuit challenging Kansas’ law was filed soon after it was passed. ${ }^{80}$ In June 2013, a lawsuit was filed in Shawnee County Court on behalf of two men who attempted to vote without presenting the required photo ID. ${ }^{81}$ The men cast provisional ballots in the 2012 General Election, but these ballots were not counted because the men did not subsequently provide adequate identification. ${ }^{82}$ The Kansas Secretary of State removed the case to federal district court. ${ }^{83}$ The two men have since dropped the lawsuit. ${ }^{84}$

After the voter ID law was enacted in Kansas, the Washington Post published an editorial saying the law was unnecessary and that the Kansas Secretary of State failed to cite even one conviction for voter fraud. ${ }^{85}$ The

${ }^{78} I d$.

${ }^{79} \mathrm{Id}$.

${ }^{80}$ Brent Wistrom, Lawsuit Filed Challenges Kansas Voter ID Law, THE Wichita EAGLE, http://www.kansas.com/2013/06/27/2865818/lawsuit-filed-challenges-kansas.html (last updated Aug. 27, 2013).

${ }^{81}$ Id.

${ }^{82} I d$.

83 John Milburn, Challenge to Kansas Voter ID Law Likely Headed to Federal Court, CJONLINE.COM, http://cjonline.com/news/2013-11-05/challenge-kansas-voter-id-law-likelyheaded-federal-court (last updated Nov. 5, 2013).

84 John Hannah, 2 Men End Federal Lawsuit Over Kansas Voter ID Law, The Kansas CiTY STAR, http://www.kansascity.com/news/government-politics/article346800/2-men-endfederal-lawsuit-over-Kansas-voter-ID-law.html (last updated Apr. 24, 2014).

${ }^{85}$ A vote Against Voting, The WAshington Post, http://www.washingtonpost.com/ opinions/a-vote-against-voting/2011/06/20/AG9es1eH_story.html (last updated Jun. 21, 2011). 
article also contends that the costs incurred by voters far outweigh the nonexistent benefits. ${ }^{86}$ Kris Kobach, Kansas Secretary of State, published a response article ${ }^{87}$ In his response, Secretary Kobach said that there were 221 documented incidences of voter fraud, including impersonation of another voter. ${ }^{88}$ Secretary Kobach explained that many of these incidences of voter fraud were not fully investigated only "because Kansas county attorneys lack the time and resources to pursue voter fraud at the expense of criminal investigations." ${ }^{\prime 9}$ However, thirty cases were fully investigated, with seven resulting in prosecutions and all seven resulting in convictions. ${ }^{90}$ Secretary Kobach noted that the number of voter fraud cases is small because they are "extremely difficult to detect." ${ }^{91}$ Even so, Secretary Kobach makes a crucial point: The important question is not merely "how many" instances of voter fraud occur, but rather "[d]oes the number of illegal votes exceed the margin of victory in a particular race? All too often, the answer is yes." 92

\section{Tennessee}

The Tennessee legislature recently passed their version of the voter photo ID law. ${ }^{93}$ Tennessee Code Annotated § 2-7-112 outlines the requirements for voter identification:

(a)(1) A voter shall complete and sign an application for ballot, indicate the primary in which the voter desires to vote, if any, and present it to a precinct registrar. In addition, the voter shall present to the precinct registrar one (1) form of identification that bears the name and photograph of the voter. The requirement to present one (1) form of identification that bears the name and photograph of the voter shall apply to persons voting pursuant to § 2-6-109; provided, however, that a person voting in accordance with

\footnotetext{
${ }^{86} I d$.

${ }^{87}$ Kris Kobach, Voter Photo ID laws Are Good Protection Against Graud, WP OpINIONS, http://www.washingtonpost.com/opinions/voter-id-laws-are-good-protection-againstfraud/2011/07/08/gIQAGnURBI_story.html (last updated Jul. 13, 2011).

${ }^{88} \mathrm{Id}$.

${ }^{89} \mathrm{Id}$.

${ }^{90}$ Kris Kobach, Voter Photo ID laws Are Good Protection Against Graud, WP OPINIONS, http://www.washingtonpost.com/opinions/voter-id-laws-are-good-protection-againstfraud/2011/07/08/gIQAGnURBI_story.html (last updated Jul. 13, 2011).

${ }^{91} \mathrm{Id}$.

${ }^{92} I d$.

93 Tenn. Code AnN. § 2-7-112 (2013).
} 
§ 2-6-401(a) and (b) ${ }^{[94]}$ or § 2-6-601 ${ }^{[95]}$ shall not be required to show an identification with a photograph of the voter. The application for ballot shall include a space for the address of the voter's current residence, and the voter shall write or print such address on the application when the voter signs the application for ballot. ${ }^{96}$

After the law was passed, it was predictably challenged in court. ${ }^{97}$ The city of Memphis and two voters challenged Tennessee's voter photo ID law in state court after election officials refused to accept a library card as a sufficient form of identification. ${ }^{98}$ The chancery court denied relief, finding the law to be constitutional, and the city and voters appealed. ${ }^{99}$ The Tennessee Court of Appeals affirmed in part, reversed in part, and ordered the county election commission to accept the library card as identification. ${ }^{100}$ The Tennessee Supreme Court reversed the Court of Appeals' decision and upheld the law requiring photo identification at the polls, ruling that lawmakers had the authority to take steps to guard against fraud. ${ }^{101}$ The Court found that "protection of the integrity of the election process empowers the state to enact laws to prevent voter fraud before it occurs, rather than only allowing the state to remedy fraud after it has become a problem.”102 Furthermore, the Court held the state had a compelling government interest in the law and the law was narrowly tailored. ${ }^{103}$

Since the passage of the law, opponents in Tennessee have argued that the law does not actually combat the issue of voter fraud. ${ }^{104}$ In addition, opponents claim the law places an undue burden on voters without actually doing anything to solve the real problem, ${ }^{105}$ which is that "voter fraud is more

\footnotetext{
${ }^{94}$ Section 401 (a) and (b) provide an exception to voters who have been hospitalized in their county of residence within twenty days of an election. TENn. CODE ANN. § 2-6-401(a); TENN. CodE AnN. § 2-6-401(b) (2013).

${ }^{95}$ Section 601 provides an exception for individuals who are permanent residents of a licensed nursing home in the individual's county of residence. TENN. CODE ANN. § 2-6-601 (2013).

96 Tenn. Code AnN. § 2-7-112 (2013).

97 Turner-Golden v. Hargett, 2012 WL 3202307 (M.D. Tenn. 2012).

${ }^{98} \mathrm{Id}$.

${ }^{99} \mathrm{Id}$.

${ }^{100}$ City of Memphis v. Hargett, 2012 WL 5265006, at*13 (Tenn. Ct. App. 2012).

101 Chas Sisk, TN Supreme Court Upholds Voter ID Law, WBIR.com (Oct. 17, 2013, 8:55 PM), http://www.wbir.com/story/news/local/2013/10/17/tennessee-supreme-court-upholdsvoter-id-law/3005259/.

102 City of Memphis v. Hargett, 2013 WL 5655807, at *11 (Tenn. 2013).

${ }^{103} \mathrm{Id}$.

104 TN Supreme Court Upholds Voter ID Law, Says It's Not an Undue Burden, THE TENNESSEAN, http://www.tennessean.com/article/20131018/NEWS02/310180091/TNSupreme-Court-upholds-voter-ID-law-says-s-not-an-undue-burden (last updated Oct. 18, 2013).

${ }^{105} \mathrm{Id}$.
} 
likely to be committed by poll workers, by stuffing ballot boxes or other techniques, than individuals trying to fool election officials by claiming to be someone else.” ${ }^{106}$ Once again, these arguments recycle factual allegations and doctrinal claims that have been repeatedly rejected by legislative debate and judicial decision. In Tennessee, these allegations were discounted by the Chancery Court, and the Tennessee Supreme Court found that due to the availability of free IDs or other methods for voting, no undue burden was placed on voters. ${ }^{107}$

\section{ISSUES RAISED CONCERNING VOTER ID LAWS IN THE UNITED STATES AND RESPONSES}

Even though court challenges to voter photo ID laws have been unsuccessful in several states, this Note will briefly review — and refute-the arguments most commonly made against such laws. As stated in the introduction, this analysis is useful for several reasons. First, states that have not enacted strict voter photo ID laws can use the arguments in this Note to supplement efforts to pass laws that will satisfy judicial review. Second, states with well-crafted and well-supported laws can use these arguments to guard against challenges from opponents. Third, at least some of the opponents should be persuaded to support voter photo ID laws because such laws are commonplace in countries around the world, including countries often cited as international role models by the very people and groups who oppose voter photo ID laws.

Opponents of voter photo ID laws argue that such laws are unnecessary as they fight a nonexistent problem-voter fraud-and have many disadvantages. ${ }^{108}$ These alleged disadvantages are that the laws disenfranchise minority and low-income voters, suppress voter turnout, and disregard public opinion. Despite the repetitiveness with which these arguments are made, courts have rejected the first two bases, when appropriate mechanisms are included in the statutes. The third basis is contrary to public opinion data.

A. Voter Photo ID Laws Do Not Disenfranchise Minority and Low-Income Voters by Implementing a Modern Day Poll Tax

One of the most common arguments against voter photo ID laws is that they implement a "poll tax" that disenfranchises people who cannot afford to

106 Id.

107 Id.

108 Voter ID Laws Penalize Disadvantaged, Minority Groups, THE DAILy ILLINI, http://www. dailyillini.com/article_fc84028f-9584-5c2d-a581-218d32bb51b3.html (last updated Sept. 26, 2012). 
purchase a photo ID or who are unable to obtain one because of disability. ${ }^{109}$ The Voting Rights Institute contends that "11 percent of Americansapproximately 23 million citizens of voting age-lack proper photo ID and, as a result, could be turned away from the polls on Election Day. Those without photo ID are disproportionately low-income, disabled, minority, young, and older voters." 110

The argument that voter photo ID laws disenfranchise minority and low-income voters is based on the premise that these laws constructively impose a tax by forcing voters to spend money on a photo ID before they can cast a ballot. ${ }^{111}$ However, states with voter photo ID laws have put safeguards in place to negate this argument. For instance, the State of Georgia offers a free voter identification card, with a photo, to any voter who does not currently possess one of the six statutorily prescribed forms of photo ID. ${ }^{112}$ Free-of-cost availability negates the existence of a financial barrier to voting. Another form of direct cost, the expenses of transportation to and from a place where ID cards are issued, and an indirect expense, lost opportunity cost from wages not earned during the time necessary to obtain the ID card, are discussed in Section V-4 below.

Likewise, in Indiana, the Bureau of Motor Vehicles (BMV) is authorized to issue an identification card. ${ }^{113}$ The BMV is prohibited from charging a fee to issue such a card and is directed to issue the ID card to any individual who does not have a valid driver's license and who will be eighteen years of age and otherwise eligible to vote in the next election. ${ }^{114}$ Between 2006 and 2012, the Indiana BMV issued 1,179,394 free ID cards. ${ }^{115}$ That number is a significant portion of Indiana's 4,875,504 eligible voters and is in addition to people who hold valid driver's licenses. ${ }^{116}$ The claim of undue burden is further reduced as Indiana also provides exemptions for persons who are indigent, who have a religious objection to having their

109 Why Voter ID laws Are Like a Poll Tax, PoLiTico, http://www.politico.com/news/stories/ 0812/79416.html (last updated Aug. 7, 2012).

110 The Real Cost of Voter ID Laws, Voting Rights InSTITUTE, http://www.democrats.org/ the-real-cost-of-photo-id-laws (last visited Oct. 19, 2013) (emphasis added).

${ }^{111}$ Ramit Plushnick-Masti \& Pete Yost, Eric Holder: Voter ID Laws are 'Poll Taxes,' HufF Post PoLiTiCs, http://www.huffingtonpost.com/2012/07/10/eric-holder-voter-id-poll-tax_n_ 1662847.html (last updated Jul. 10, 2012).

112 GA. CodE ANN. § 21-2-417 (2012).

113 IND. CODE § 9-24-16-10 (2013).

${ }^{114} \mathrm{Id}$.

115 Connie Lawson, MEDIA Information Guide for Indiana 2012 General Election, SECRETARY OF STATE, http://www.in.gov/sos/elections/files/2012_General_ Election_Media_Guide_with_Attachments.pdf (last updated Feb. 6, 2013). 116 This data is based on Indiana's eighteen \& over population according to the 2010 Census. 2010 Census Interactive Population Search, U.S. CENSUS, http://www.census.gov/2010 census/popmap/ipmtext.php?fl=17 (last visited Feb. 11, 2014). A person in Indiana cannot hold both a driver's license and an identification card. Identification Cards, BUREAU OF Motor Vehicles, http://www.in.gov/bmv/2358.htm (last visited Feb. 11, 2014). 
photograph taken, or who reside in a state-licensed facility that also serves as the polling location. ${ }^{117}$

Similarly accommodating procedures are in place in Kansas and Tennessee. In Kansas, a person is eligible for a free photo ID card if the person is registered to vote, does not currently possess government-issued identification documentation for voting purposes, and can provide a copy of voter registration status. ${ }^{118}$ In addition, Kansas goes a step further and provides a free birth certificate, which is needed to obtain a free photo ID card. ${ }^{119}$ In Tennessee, a registered voter who does not have a governmentissued photo ID is able to obtain a free photo ID from the Department of Safety and Homeland Security. ${ }^{120}$ The conclusion to be drawn from these four states is unmistakable. Each state has implemented mechanisms to ensure that minority and low-income voters are not disenfranchised because voters are able to obtain a photo ID at no cost.

Not only do voter photo ID laws not disenfranchise voters, they also promote full enfranchisement of valid voters. The main purpose of voter photo ID laws is to reduce voter fraud. ${ }^{121}$ It should be remembered that voter fraud dilutes the vote of legitimate voters by allowing improper votes to be counted and, as the Seventh Circuit observed, dilution has long been recognized as a form of impairment of the right to vote. ${ }^{122}$

\section{B. Voter Photo ID Laws Do Not Reduce Voter Turnouts}

Many factors affect voter turnout statistics. One factor is the presence or absence of the presidential election on the ballot. To keep the data examined in this Note as uniform as possible and thereby promote meaningful comparisons, this Note will examine only voter turnout data from election years in which the President is on the ballot. ${ }^{123}$

Voter turnout data does not specifically account for the number of people who avoided the polls entirely because they knew of the photo ID requirement and knew that they could not satisfy it.

Indeed, little empirical evidence exists that quantifies the number of individuals who do not present themselves at

\footnotetext{
117 Indiana Election Division, Exemptions, http://www.in.gov/sos/elections/2624.htm (last visited Oct. 21, 2013).

${ }^{118}$ Valid Forms of Photographic Identification, GOT VOTER ID?, http://www.gotvoterid.com/ valid-photo-ids.html\#feewaver (last visited Oct. 21, 2013).

${ }^{119} \mathrm{Id}$.

${ }^{120}$ Department of Safety and Homeland Security, Voter Photo ID, http://www.tn.gov/safety/ photoids.shtml (last visited Oct. 21, 2013).

${ }^{121}$ Crawford v. Marion Cnty. Election Bd., 472 F.3d at 952.

${ }^{122} \mathrm{Id}$.

123 This note will only examine voter turnout for Presidential elections in 2004, 2008, and 2012.
} 
Indiana's polling places because they know they cannot meet the photo identification requirement. For instance, no one has ever polled Indiana residents to measure how many persons did not show up at Indiana's polls because they lacked photo identification. ${ }^{124}$

Nonetheless, voter turnout data does show that voter turnout after the voter photo ID laws went into effect was generally equal to or higher than voter turnout from before the laws. It seems unlikely that a person who did not vote before the law went into effect avoided the polls only because of the ID requirement. It seems more reasonable to conclude that he or she avoided the polls for other reasons, including dissatisfaction with candidates, a dislike of the political system, or disillusionment because he or she thinks the vote would not really matter. Furthermore, the decision not to vote often springs from multiple motivations. "[I]n one national study of voters (involving the 2008 presidential primaries on Super Tuesday), all of the voters who said lack of identification was a reason for not voting indicated that there were also other reasons why they did not cast their ballots, such as 'bad weather' and 'forgot to vote.","125

\section{Georgia}

Georgia's voter photo ID law became effective in 2006. In 2004, Georgia had 5,878,168 registered voters. In that year's General Election, 3,317,336 people voted. ${ }^{126}$ This is a turnout of 56.43 percent. For the 2008 General Election, after the photo ID law went into effect, voter turnout in Georgia was 62.5 percent. ${ }^{127}$ For the 2012 General Election, 3,919,355 people cast ballots, out of a pool of 5,428,980 registered voters. ${ }^{128}$ That is a turnout rate of 72.19 percent. The data from these elections in Georgia leads

124 Michael J. Pitts \& Matthew D. Neumann, Documenting Disenfranchisement: Voter Identification During Indiana’s 2008 General Election, 25 J. L. \& PoL. 329, 344 (2009).

${ }^{125} \mathrm{Id}$.

1262004 General Election Turnout Rates, United States Elections Project, http://elections.gmu.edu/Turnout_2004G.html (last updated Dec. 28, 2011).

1272008 General Election Turnout Rates, United States Elections Project, http://elections.gmu.edu/Turnout_ 2008G.html (last updated Mar. 31, 2012). 2006 was the year the voter ID law went into effect in Georgia. This year, the state had a very low turnout of only 35.1\%. See 2006 General Election Turnout Rates, United StATES ElECtions PROJECt, http://elections.gmu.edu/Turnout_2006G.html (last updated Dec. 28, 2011). There was also a very low turnout of only $40.5 \%$ in the 2010 General Election. This highlights a pattern of Georgians voting less in non-Presidential elections. See 2006 General Election Turnout Rates, United States Elections Project, http://elections.gmu.edu/Turnout_ 2010G.html (last updated Feb. 4, 2012).

${ }^{128}$ Georgia Election Results, Statewide Results, http://results.enr.clarityelections.com/GA/ 42277/113204/en/ summary.html (last updated Nov. 21, 2012). 
to one conclusion: there has been a consistent upward trend of voter turnout in presidential elections in Georgia even with the enactment of a strict voter photo ID law.

\section{Indiana}

Indiana's voter photo ID law went into effect in 2005. In the 2004 General Election, 58 percent $(2,512,142$ out of 4,296,602) of registered voters voted. ${ }^{129}$ In 2008, 2,805,986 out of the 4,514,759 registered voters voted. ${ }^{130}$ This is a 62 percent turnout rate. In 2012, 58 percent of the registered voters voted in the General Election. ${ }^{131}$ While there is a decrease in voter turnout from 2008 to 2012, the effect is a return to the same voter turnout rate as in 2004. In that sense, since Indiana enacted its voter photo ID law, there has been no reduction in voter turnout below the pre-law level. Furthermore, the decrease in voter turnout between 2008 and 2012 is relevant only if attributable to a negative impact on the voter photo ID law. Several factors contradict such a conclusion. The increase in the voter turnout rate from 2004 to 2008 may be attributed to the identity of the candidates on the ballot, including the first African-American presidential candidate, Barack Obama. Interest in his candidacy sparked an increase in voter participation rates around the nation. ${ }^{132}$ Thus, the lower participation rate in 2012 as compared to 2008 is a reduction, only in the sense that a near record turnout rate was not repeated. Second, the reduction in turnout in 2012 may also be attributed to candidate identity, including a decrease in President Obama's popularity in Indiana, as Indiana went from a "blue state" to a "red state" in these two elections. ${ }^{133}$ On the other side of the aisle, the polarizing effect of the Republican Primary race for United States Senate, which culminated in the defeat of six-term Senator Richard Lugar, likely caused some Republican voters to stay away from the polls. ${ }^{134}$ Apart from such considerations-or

\footnotetext{
${ }^{129}$ General Election Turnout and Registration, 2004 General Election, http://www.in.gov/ sos/elections/files/2004_.Municipal_Registration_and_Turnout.pdf (last updated Nov. 2, 2004).

${ }^{130}$ General Election Turnout and Registration, 2008 General Election, http://www.in.gov/ sos/elections/files/2008_election_turnout.pdf (last updated Nov. 4, 2008).

${ }^{131}$ General Election Turnout and Registration, 2012 General Election, http://www.in.gov/ sos/elections/files/2012_General_Election_Turnout_Report.pdf (last updated Nov. 6, 2012). While outside the scope of this Note, James H. Madison's book, The Indiana Way, gives a complete history of Indiana's voter turnout from 1824 through 1984. This highlights how inconsistent voter turnout has been all throughout Indiana's history, long before the Voter ID law was enacted. James H. Madison, The Indiana WAY, 330 (Ind. Univ. Press 1986).

${ }^{132}$ Andy Barr, 2008 Turnout Shatters All Records, PoLITICO, http://www.politico.com/news/ stories/1108/15306.html (last updated Nov. 5, 2008).

${ }^{133}$ Indiana, 270TOwIN, http://www.270towin.com/states/Indiana (last visited Feb. 8, 2014).

${ }^{134}$ Election Results, INDIANA ELECTION DIVISION, http://www.in.gov/apps/sos/primary/sos

_primary12?page $=$ office \&countyID=-1\&partyID=-1\&officeID=10\&districtID=-1\&

districtshortviewID=-1\&candidate= (last updated Jun. 5, 2012).
} 
despite them-it is clear that the state's voter photo ID law did not decrease voter turnout below 2004 levels. ${ }^{135}$

\section{Kansas}

In Kansas in 2012, 1,182,771 of the 1,771,252 registered voters voted; a 66.8 percent turnout. ${ }^{136}$ There was a 72.3 percent turnout in the 2008 General Election ${ }^{137}$ and a 71.6 percent turnout in the 2004 General Election. ${ }^{138}$ Kansas' voter photo ID law was passed in 2011. Voter turnout did drop for the 2012 election. However, the decrease in turnout is relatively small, and it is unclear what factors caused the decrease in voter turnout for that election. It is possible that the decrease resulted from newness of the law, a lack of time for people to become aware of the ease of obtaining a free government identification card, or other factors, such as dissatisfaction with candidates on the ballot. ${ }^{139}$ More information will be available on the impact of the voter ID law after the 2016 General Election and these results will merit close analysis.

\section{Tennessee}

The voter photo ID law in Tennessee was passed in 2011. As in Kansas, the law was in place for the first time during the 2012 General Election. ${ }^{140}$ For the 2004 General Election, Tennessee had a voter turnout rate of 47.3 percent. ${ }^{141}$ In the 2008 Election, voter turnout jumped to 60.34 percent. ${ }^{142}$ In

\footnotetext{
135 There was a sharp decline the voter turnout in 2006 and 2010. This is likely because it was not a Presidential election. See generally Voter Registration and Turnout Statistics, INDIANA ELECTION Division, http://www.in.gov/sos/elections/2983.htm (last visited Oct. 21, 2013).

136 Elections Statistics, State of Kansas Office of the SeCretary of State, http://www.kssos.org/elections/el ections_statistics.html (follow “2012 General Election Official Turnout” hyperlink)

137 Elections Statistics, State of KANSAs OfFicE of THE SECRETARY OF StATE, http://www.kssos.org/elections/el ections_statistics.html (follow “2008 General Election Official Turnout" hyperlink)

138 Elections Statistics, State of Kansas Office of the Secretary of State, http://www.kssos.org/elections/el ections_statistics.html (follow “2004 November 2nd General Election Official Turnout” hyperlink)

${ }^{139}$ As of the 2010 Census, Kansas' population was 87.2\% white. The voter ID law is claimed to suppress the vote of minorities. State and County Quick Facts, U.S. CENSUS BUREAU, http://quickfacts.census.gov/qfd/states/20000.html (last updated Jun. 27, 2013). This is higher than the national average of $77.9 \%$ white population. State and County Quick Facts, U.S. CENSUS BuREAU, http:/quickfacts.census.gov/qfd/states/00000.html (last updated Jun. 27, 2013).

140 NATiOnAl CONFERENCE OF STATE Legislatures, supra note 27.

141 Statistical Analysis of Voter Turnout for the November 2, 2004 Election, http://www.tn.gov/sos/election/data/tur nout/2004-11.pdf (last visited Oct. 21, 2013).

142 Statistical Analysis of Voter Turnout for the November 4, 2008 General Election, http://www.tn.gov/sos/election/ data/turnout/2008-11.pdf (last visited Oct. 21, 2013).
} 
2012, voter turnout for the General Election remained essentially steady at 59.33 percent. ${ }^{143}$ Even though there has only been one General Election with the voter photo ID in place, the law did not adversely impact voter turnout in a meaningful way.

The graph below shows voter turnout statistics in a line graph format. Each line corresponds to a different state. In general, there was an increase in voter turnout after the voter photo ID laws went into effect.

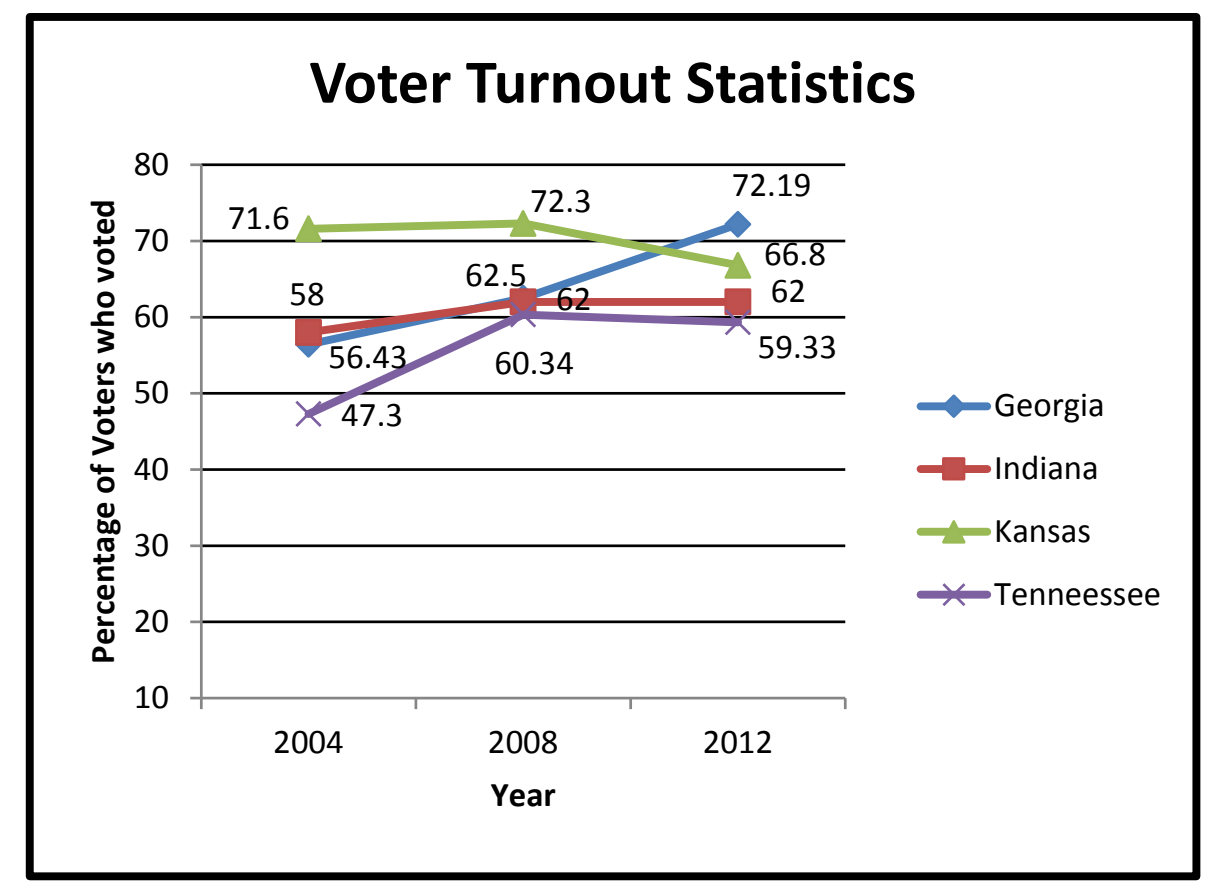

\section{Voter Photo ID Laws Are Approved By Most Voters}

Another common argument against voter photo ID laws is that "the public" dislikes them because they are overly burdensome and make voting too difficult. ${ }^{144}$ To the contrary, a recent nationwide study found that voter photo ID laws receive bipartisan support from the public. ${ }^{145}$ A 2013 USA

143 Statistical Analysis of Voter Turnout for the November 6, 2012 Election as Submitted by the Counties, http://www.tennessee.gov/sos/election/data/turnout/2012_11\%20Turnout.pdf (last visited Oct. 21, 2013).

${ }^{144}$ Attacks on Voting Rights, FAIR ELECTIONS LEGAL NETWORK, http://www.fairelections network.com/attacks-voting-rights (last visited Feb. 15, 2014).

145 Susan Page, Poll: Americans Support Fine-Tuning Election Policy, USA ToDAY (Oct. 14, 2013, 6:45 PM), http://www.usatoday.com/story/news/politics/2013/10/14/americanselection-policy-usa-today-bipartisan-policy-center-poll/2983159/. 
TODAY/Bipartisan Policy Center poll found voter photo ID laws have an overall approval rating of 80 percent. ${ }^{146}$ Among Republicans, the approval rate is 95 percent; ${ }^{147}$ among Democrats, the approval rate is 70 percent. ${ }^{148}$ Eighty-five percent of Independents approve of voter ID laws. ${ }^{149}$ The poll also addressed the perceived ease or difficulty of voting. Of the people surveyed, three out of four considered voting to be an easy task. ${ }^{150}$ Only four percent considered voting to be a difficult task. ${ }^{151}$ The causes of perceived difficulty for the four percent were not identified and could be based on a variety of causes unrelated to voter photo ID laws, such as permitted voting hours and required voting places.

\section{VOTER ID LAWS IN OTHER COUNTRIES}

States in the United States are hardly the first governments in the world to implement voter photo identification requirements. Strict voter photo ID laws are common in countries around the world and laws requiring a voter to show proof of identity before casting a ballot exist in several democratic countries. In fact, outside of the United States, these types of laws appear to be the norm in countries with democratic elections. It is worthwhile to examine the experiences of other countries for two important reasons. First, they confirm the rationale offered in the United States to support voter photo ID laws. Second, an understanding of voter photo ID procedures in other countries can help lawmakers in the United States enact laws that are consistent with American culture and American federalism. This Note will examine the laws of six countries on four continents: Brazil in South America, Canada in North America, the Republic of China (Taiwan) in Asia, and three countries in the European Union.

\section{A. Brazil}

In Brazil, all literate citizens between eighteen and seventy years of age are required to vote in all elections. ${ }^{152}$ Failing to vote is not a legal option. Article Fourteen of the Constitution of Brazil outlines the requirements for voting:

\footnotetext{
${ }^{146} I d$.

${ }^{147} \mathrm{Id}$.

${ }^{148} \mathrm{Id}$.

149 Susan Page, Poll: Americans Support Fine-Tuning Election Policy, USA TodAY (Oct. 14, 2013, 6:45 PM), http://www.usatoday.com/story/news/politics/2013/10/14/americanselection-policy-usa-today-bipartisan-policy-center-poll/2983159/.

${ }^{150} I d$.

${ }^{151} \mathrm{Id}$.

152 Constituicao Federal [CF] [Constitution] art. 14 (Braz.), available at http://web.mit. edu/12.000/www/m 2006/teams/willr3/const.htm.
} 
Paragraph 1. Electoral enrollment and voting are:

I. mandatory for persons over eighteen years of age;

II. optional for:

a. the illiterate;

b. those over seventy years of age;

c. those over sixteen and under eighteen years of age. ${ }^{153}$

Since voting is mandatory for millions of Brazilians, the government has a strong incentive to implement measures to regulate the election process. To achieve efficient and fair elections, the Brazilian government issues an electoral document that contains information relating to the date and place where the person is registered to vote. ${ }^{154}$ This process of voter registration is done when a person becomes eighteen years old or moves to a new residence. ${ }^{155}$ In addition to the obligation to vote, each voter is obligated to prove his or her identity before voting. ${ }^{156}$ To avoid misuse of another person's electoral document, election officials check identification. ${ }^{157}$ A person's identification can be established by using the National Identification number, a passport, or a driver's license, each of which has a photograph. ${ }^{158}$ The photo ID requirement is regulated under Law 4737 of the Electoral Code, which dates back to 1965 . $^{159}$

To protect the integrity of its elections, Brazil is not content with its voter photo ID laws. Instead, the country will soon enact an even more secure voting system. Brazil has been collecting fingerprints and plans to use biometric technology to verify the identity of voters. ${ }^{160}$ The process began in 2008, and the goal was to identify roughly twenty-two million voters by their fingerprints in time for the 2014 Presidential Election. ${ }^{161}$ The reason for this new process is that it further reduces the opportunities for voter fraud and "makes it impossible for a person to try to pretend to be somebody else."162

${ }^{153} \mathrm{Id}$.

${ }^{154}$ Law 4737 from 1965 (as translated by Stella Emery Santana, Professor of Law, Faculdade Espírito-Santense de Administração (FAESA).

${ }^{155} I d$.

${ }^{156} I d$.

${ }^{157} I d$.

${ }^{158} I d$.

${ }^{159} \mathrm{Id}$.

${ }^{160}$ André Richter, In Brazil, 22 Million Voters to be Identified Through Biometrics in 2014, EBC, http://www.ebc.com.br/english/2013/10/in-brazil-22-million-voters-to-be-identifiedthrough-biometrics-in-2014 (last updated Jul. 10, 2013). Some countries go even further than requiring a photo ID. For instance, elections in Egypt require a voter to dip a finger in a phosphorous ink. The ink mark prevents a person from voting a second time. Wendell Steavenson, Egyptian Elections: The Lantern and the Light Bulb, THE NEW YORKER, http://www.newyorker.com /online/blogs/wendell-steavenson/2011/11/the-lantern-and-thelightbulb.html (last updated Nov. 28, 2011).

${ }^{161}$ Richter, supra note 160.

${ }^{162}$ Id. 
Estimates indicate that "over twenty million voters in 762 municipalities" used the biometric machines in the first round of voting, which took place on October 5, 2014. ${ }^{163}$ This system, which is expected to be fully functional by 2020, will "virtually eliminate the incidence of people voting on behalf of others." 164

\section{B. Canada}

Canada, one of the world's most mature and highly respected democracies, also requires voters to show a form of identification when casting a ballot. ${ }^{165}$ Canada Election Act, part nine, section 143, outlines Canada's voter ID requirements:

(1) Each elector, on arriving at the polling station, shall give his or her name and address to the deputy returning officer and the poll clerk, and, on request, to a candidate or his or her representative.

Proof of identity and residence

(2) If the poll clerk determines that the elector's name and address appear on the list of electors or that the elector is allowed to vote under section 146, 147, 148 or 149 , then, subject to subsection

(3), ${ }^{[166]}$ the elector shall provide to the deputy returning officer and the poll clerk the following proof of his or her identity and residence:

(a) one piece of identification issued by a Canadian government, whether federal, provincial or local, or an agency of that government, that contains a photograph of the elector and his or her name and address. ${ }^{167}$

\footnotetext{
163 Chesney Hearst, Biometic Voting During Brazilian Runoff Elections, THE Rio Times, http://riotimesonline.com/brazil-news/rio-politics/biometric-voting-during-brazilian-runoffelections/ (last updated Oct. 26, 2014).

164 Sarah de Sainte Croix, Brazil's Most Secure Voting Ever, THE Rio Times, http://riotimesonline.com/brazil-news/front-page/brazils-most-secure-voting-ever/ ～(last updated May 30, 2010).

${ }^{165}$ Canada Elections Act, Part 9, Section 143, available at http://www.elections.ca/content. aspx?section=res\&dir=loi/fel/cea\&document=part09\&lang=e\#sec143

${ }^{166}$ Subsection (3) allows a voter to prove his or her identity by taking an oath if he or she is accompanied by another elector whose name appears on the list and who can provide the documents required by section 2 and who will vouch for the voter. Id.

${ }^{167}$ Presenting a photo ID is not the only option for providing proof of identity. A voter may also provide "two pieces of identification authorized by the Chief Electoral Officer, each of
} 
Canada's voter photo ID law was amended in 2007 to require this proof of identification. ${ }^{168}$ After the federal government amended the law, it was challenged in court by two anti-poverty activists and a visually impaired woman. ${ }^{169}$ The court ruled that while the law "could interfere with some citizens' ability to vote, [it was] needed to prevent fraud and ensure public confidence in the electoral system.”170

\section{Republic of China (Taiwan)}

The Republic of China (Taiwan) is another country that has implemented voter photo ID laws to keep elections secure. To cast a vote, a voter must receive a ballot by presenting an ID card. ${ }^{171}$ Article fifty-two of the Household Registration Act of the Republic of China says, "The format, content, photo specification of the National ID Card and Household Certificate shall be stipulated by the central competent authority." 172 According to Article twenty-one of "The Issuance and Photo File Content of the National ID Card and Household Certificate Management Regulation” promulgated by the Ministry of Interior, the National ID card shall contain, among many things, a photo. ${ }^{173}$

Case information and commentary on the Republic of China's voter photo ID law is very difficult to find, likely because the Republic of China is a civil law country and does not utilize reported judicial decisions as law. ${ }^{174}$ Thus, one must look to other sources for information about reactions to voter photo ID laws in the Republic of China. The main reason voter photo ID laws are challenged or opposed in states in the United States is because they require everyone to obtain a photo ID on their own. In the Republic of China, National ID cards are issued by the national government to all eligible people upon household registration, an act already required of all citizens. ${ }^{175}$ For citizens of the Republic of China, this coordinated registration system

which establish the elector's name and at least one of which establishes the elector's address.” Id.

168 Tamsyn Burgmann, Canada Voter ID Laws Challenged in BC Court of Appeal, HufFPosT BRITISH COLUMBIA, http://www.huffingtonpost.ca/2013/02/04/canada-voter-id-lawschallenge-bc-court_n_2613784.html (last updated Feb. 4, 2013).

${ }^{169}$ Id.

170 This ruling is being appealed and the B.C. Civil Liberties Association has joined the proceedings. $I d$.

${ }^{171}$ Civil Servants Election and Recall Act, art. 18 (Amended May 25, 2011) (Taiwan).

${ }^{172}$ Household Registrations Act, Laws and Regulations Database of the Republic of CHINA, http://law.moj.gov.tw/Eng/LawClass/LawAll.aspx?PCode=D0030006 (last updated May 25, 2011).

${ }^{173} \mathrm{Id}$.

174 The Legal System of Taiwan, ColumBus ScHOOL OF LAw, http://www.law.edu/

ComparativeLaw/Taiwan/ (last visited Feb. 15, 2014).

${ }^{175}$ Household Registrations Act, supra note 172. 
addresses the concern that people in the United States express, which is that the burden of obtaining a photo ID will cause people not to vote.

Even with coordinated registration, however, people in the Republic of China are still required to travel to a household registration office to register a house and obtain a National ID card. ${ }^{176}$ Despite this requirement, there is no evidence that the people of the Republic of China have written articles complaining about this law or filed any lawsuits to overturn it. This travel requirement is similar to the requirement in the United States, where certain states require would-be voters to travel to an office that issues photo IDs. In the Republic of China, the idea of voter photo ID is simply considered a routine part of the citizen-government relationship. Like other aspects of citizenship in the Republic of China, obligations - whether registering one's home or getting a photo ID to vote-are not thought of as "burdens." Citizens of the United States would likely not tolerate a household registration system, but, as the 2013 USA TODAY/Bipartisan Policy Center poll points out, the vast majority (eighty percent) of people in the United States approve of voter photo ID laws, which means the vast majority do not consider the law's requirements to be as burdensome. ${ }^{177}$

\section{European Union}

Many countries in the European Union have enacted voter photo ID laws. Spanish law provides: "On election day, take identification and any voting papers to the polls . . . . After exiting the booth, go to the attendant, show identification and hand in the envelope." ${ }^{178}$ A voter in Spain is not able to register to vote without providing an acceptable photo ID, such as a passport. ${ }^{179}$ French law states, "French voters, once registered, are sent a voter's card providing them the address of their polling station, at least three days prior to the election. . . In the more populated municipalities, a recognized identity document (i.e. French identity card . . . or passport) is required while presenting a voter's card being optional." ${ }^{180}$ French identity cards $^{181}$ and passports ${ }^{182}$ both contain photographs of the owner. Italian law

\footnotetext{
176 Article 61, Household Registrations Act, LAWs AND REgulations DataBASE of THE REPUBLIC OF CHINA, http://law.moj.gov.tw/Eng/LawClass/LawAll.aspx?PCode=D0030006 (last updated May 25, 2011).

${ }^{177}$ Page, supra note 145.

${ }^{178}$ Voting in Spanish Elections, ANGLOINFO, http://balearics.angloinfo.com/information/ moving/voting/ (last visited Oct. 20, 2013).

${ }^{179} I d$.

180 Questions About Voting, LÉGISlatives Assemblée Nationale, http://www.electionslegislatives.Fr/en/voting.asp (last visited Oct. 20, 2013).

${ }^{181}$ ID Cards and the Bureaucratic Maze, FRANCE 24, http://www.france24.com/en/ 20100224-id-cards-bureaucratic-maze/ (last updated Feb. 25, 2010).

${ }^{182}$ Kelly Shetsky, How to Obtain a French Passport, USA TODAY, http://traveltips.usatoday. com/obtain-french-passport-21095.html (last visited Feb. 15, 2014).
} 
provides that " $[\mathrm{u}] \mathrm{p}$ to ten days before elections, voters are sent the Electoral Certificate (Certificato Elettorale) which has the personal identifying data and information on where to go to vote." ${ }^{183}$ On Election Day, "[t]he Electoral Certificate and valid photo identification (passport) must be presented when voting. The voter will be given two cards, one to elect a candidate to the commune council and one to the city council." 184 The policy that underlies the identification requirements in each of these countries is promoting the integrity of elections.

These examples make a meaningful contribution to debate about voter photo ID laws in the United States because each are mature, respected democracies, and cumulatively they indicate the degree to which voter photo ID laws are normative outside the United States.

\section{THE BENEFITS OF VOTER PHOTO ID LAWS}

\section{A. Cost-benefit analysis}

There are costs associated with voter ID laws, as they require each voter to obtain a state or federal government-issued ID. This task involves costs in terms of money, time, and transportation. In Indiana, for instance, the nominal cost of an identification card is $\$ 11.50 .{ }^{185}$ The value of a person's time to get to the BMV (or similar office) to obtain the ID should also be recognized. Additionally, for those people who work during the hours the $\mathrm{BMV}$ is open, it may not be easy to get away from the workplace, and obtaining the ID may involve a lost opportunity cost in the form of foregone wages. Obtaining an ID also requires a mode of transportation. Not everyone owns a car and persons with disabilities may have difficulty securing transportation to a BMV office. Any regulation of the right to vote involves costs, but costs are acceptable as long as they are offset by other measures that eliminate or reduce them. In addition, even if all costs associated with voter photo ID laws are not eliminated, they are nonetheless acceptable, if outweighed by the policies that support such laws.

With regard to the direct cost of the ID card itself, states with strict voter photo laws have implemented various methods to enable people in acquiring an ID card for free, thereby eliminating the direct costs. All four states in the United States that have strict voter photo ID laws provide the identification card for free. ${ }^{186}$ For people who work full time or have multiple

\footnotetext{
${ }^{183}$ Voting in Italy, for Foreigners, ANGLOINFO, http://rome.angloinfo.com/information/ moving/voting/ (last visited Oct. 20, 2013).

${ }^{184}$ Id.

${ }^{185}$ Fee Chart, Indiana Bureau of Motor VehiCles, http://www.in.gov/bmv/files/Fee_ Chart.pdf (last visited Mar. 11, 2014).

${ }^{186}$ GA. CoDE ANN. § 21-2-417 (2012); IND. CODE § 9-24-16-10 (2013); Got VOTER ID?, supra note 118; Department of Safety and Homeland Security, supra note 120.
} 
jobs, these states accommodate work schedules by extending the operating hours of offices where ID cards are obtained. For example, many of the license branches in Indiana offer extended hours on certain weekdays and are open on Saturdays. ${ }^{187}$ Such extended hours reduce or eliminate the lost opportunity cost that would arise from lost wages. Public transportation is available to help people get to offices where ID cards are obtained. Many non-profit groups and community centers provide transportation to doctor's offices and grocery stores, ${ }^{188}$ so they could easily provide transportation to photo ID issuing offices. In addition, the political parties would have a strong Get Out the Vote ("GOTV”) incentive to provide transportation as a part of their GOTV initiative. As a result, the direct cost of transportation can be eliminated or reduced.

Significantly, there is another potent solution to the burden of transportation argument: absentee voting. In addition to being able to obtain a photo ID card at no cost from a license branch with extended hours, people are able to vote absentee-by-mail without having to show a photo ID. ${ }^{189}$ This option further relieves the burden on voters and places them in the same position that existed before enactment of voter photo ID laws. One group who benefits from this option to vote absentee is disabled persons, who are relieved of the need to find transportation to a license branch to obtain an ID. This ability to vote absentee-by-mail also eliminates the burden on lowincome voters who live in cities and towns without extensive public transportation systems or transportation provided by non-profit groups and community centers. Georgia and Kansas both permit a voter to vote absentee without providing any excuse. ${ }^{190} \mathrm{~A}$ voter in Indiana can cast an absentee ballot by invoking any one of nine reasons. ${ }^{191}$ In Tennessee, a voter may vote absentee for any reason at all within the early voting period, which runs from twenty days to five days before the election. ${ }^{192}$ This ability to vote absentee without an ID rebuts concerns of disenfranchising low-income voters who cannot afford a photo ID and disabled voters who are unable to get to the appropriate office to obtain a photo ID.

187 Indianapolis - Madison Avenue License Branch, BurEAu of Motor Vehicles, http://www.in.gov/bmv/2480.htm (last visited Oct. 21, 2013).

188 Southern Indiana Transportation Services (SITS), BLUE RIVER SERVICES, INC., http://www.brsinc.org/index.php?option=com_content\&view=article\&id=87\&Itemid=61 (last visited Mar. 9, 2013).

${ }^{189}$ Voter Identification Laws, LONG DisTANCE VOTER, http://www.longdistancevoter.org/ voter_identification\#.Uxn6FEphv3M (last updated Feb. 9, 2014).

${ }^{190}$ Absentee and Early Voting, NATIONAL CONFERENCE OF STATE LEGISLATURES, http://www.ncsl.org/research/elections-and-campaigns/absentee-and-early-voting.aspx (last visited Jan. 25, 2014).

191 Absentee Voting, INDIANA ELECTION Division, http://www.in.gov/sos/elections/2402.htm (last visited Jan. 25, 2014).

192 Absentee Voting, TenNESSEE SECRETARY OF STATE, http://www.tn.gov/sos/election/bymail.htm\#2 (last visited Jan. 25, 2014). 
The conclusion that follows from these cost-eliminating mechanisms and alternatives is straightforward: while some costs are associated with voter photo ID laws, they should not prevent states from implementing such laws. The law precludes only those voting regulations that unduly burden the right to vote. So long as the mechanisms of implementation are mindful of the costs imposed and take meaningful steps to reduce them, voter photo ID laws comply with this standard.

Furthermore, complete elimination of costs imposed by voter ID laws should not be a requirement and the presence of some costs is not a legitimate criticism of voter photo ID laws. As discussed below, jury service is another civic duty that involves some of the same costs as voter photo ID, e.g. direct costs incurred to travel to and from the courtroom, and conflicts with hours of employment. In addition, jury service can involve a very real lost opportunity cost in terms of lost wages or income. ${ }^{193}$ This loss is magnified in lengthy trials and can have a significant impact on self-employed people. Even so, exemption from jury duty has been increasingly limited in recent decades, and a trend is emerging to "abolish all exemptions from jury duty." ${ }^{194}$ Despite the costs of jury service, it is seen as an acceptable burden because the costs are overshadowed by the value placed on the jury system.

Similarly, the integrity of the election process is an overarching value that outweighs whatever costs remain after states take meaningful steps to reduce them. The benefit of secure elections and confidence in the integrity of government far outweigh the costs involved in requiring identification. Significantly, the costs of these laws in the United States are much smaller than in other countries where these laws are considered a normal aspect of the election process.

The need for meaningful measures to reduce the various forms of cost associated with voter photo ID laws is confirmed by those cases where voter photo ID laws have been struck down. The common factor in each of these cases is that the costs imposed by voter photo ID laws had not been meaningfully contained by mechanisms of implementation. Recently, Pennsylvania's law was struck down by the Commonwealth Court of Pennsylvania, ${ }^{195}$ which is one of Pennsylvania's two statewide intermediate appellate courts. ${ }^{196}$ The law was struck down because "[v]oting laws are

\footnotetext{
193 Karen Datko, Jury Duty: Can You Afford It?, MSN MoNEY, http://money.msn.com/ saving-money-tips/post.aspx?post=186b1d1d-5c31-4a09-a0de-ab3671f98751 (last updated Feb. 16, 2012).

194 William Burnham, Introduction to the LAW AND Legal System of the United STATES, 89 (4th ed.).

195 Berman, supra note 30.

${ }^{196}$ Commonwealth Court of Pennsylvania, The Unified Judicial System of Pennsylvania, http://www.pacourts.us/courts/commonwealth-court/ (last visited Jan. 18, 2014).
} 
designed to assure a free and fair election” ${ }^{197}$ and, according to this court, Pennsylvania's "voter ID law does not further this goal." 198 The burden imposed by Pennsylvania's law was viewed by the court as being too high in comparison to the claimed benefit, in large part, because of the relatively small number of offices where ID could be obtained. On this matter the court concluded:

There are 9,300 polling places in the state, but only seventyone DMV offices. There are only five DMV offices for the entire city of Philadelphia, none in nine counties and the [ones] in sixteen counties offices are only open one or two days a week. "The Voter ID Law does not contain, on its face, any valid non-burdensome means of providing compliant photo ID to qualified electors." 199

Because of this limitation, the court observed that while there are "hundreds of thousands who lack compliant photo ID, only 17,000 photo IDs for voting purposes have been issued." 200 The court also noted that "[s]ince the 2012 election, fewer than 150 new voting IDs had been issued by the state per month." ${ }^{201}$ In other words, the problem with the Pennsylvania law is not the concept of voter photo ID; the problem-which can be remedied legislatively-is one of inadequate mechanisms to implement it.

In contrast to the situation in Pennsylvania, the Indiana BMV has issued 1,179,394 free ID cards between 2006 and 2012. ${ }^{202}$ There is also at least one BMV office per county. ${ }^{203}$ This relative ease of obtaining a free photo ID, combined with the number of IDs issued, is part of the reason Indiana's voter ID law was upheld. ${ }^{204}$ Similarly, Kansas has a license branch in 104 out of 105 counties. ${ }^{205}$ If Pennsylvania would enact methods to make it easier for people to obtain an ID, that law should be upheld. Pennsylvania is a good example of how improperly implemented voter ID laws do not further the purpose of making elections more secure. However, if states enact the proper legislation, voter photo ID laws can have the benefit of promoting

\footnotetext{
197 Rick Lyman, Pennsylvania Voter ID Law Struck Down as Judge Cites Burden on Citizens, THE NEW YoRK TIMES, http://www.nytimes.com/2014/01/18/us/politics/ pennsylvania-voter-id-law-struck-down.html?hp\&_r=1 (last updated Jan. 17, 2014). ${ }^{198} \mathrm{Id}$. 
a secure electoral system, while at the same time containing burdens on voters.

Similar to the situation in Pennsylvania, the voter photo ID law in Wisconsin was challenged on the ground that it imposed undue burdens on voters. The League of Women Voters in Wisconsin challenged the 2011 voter photo ID law in state court. ${ }^{206}$ The Circuit Court declared that the law violated the Wisconsin constitution because the law placed an undue burden on voters. ${ }^{207}$ When the Court of Appeals certified the appeal, it identified one of the problems with the law, as seen by the Circuit Court, as being that "even qualified electors may not vote in an election unless they display acceptable government-authorized photo identification either at the polls or to election officials by 4:00 p.m. on the Friday following the election." ${ }^{208}$ Even so, the Wisconsin Court of Appeals overturned the ruling of the trial court. ${ }^{209}$ The Court of Appeals held that the law was not facially unconstitutional because the plaintiffs failed to "show[] that the photo identification requirement is on its face an 'additional qualification' for voting, as opposed to a voter registration regulation that allows election officials 'to ascertain whether the person offering to vote possessed the qualifications required." ${ }^{210}$ The Supreme Court of Wisconsin denied a petition to certify the appeal. ${ }^{211}$ Put differently, the "burden" imposed by the requirements of a photo ID is not a disenfranchising "burden on the right to vote." Instead, voter photo ID laws are one of several methods to ascertaining voter qualification.

However, while the state lawsuit was progressing, a group of voters and advocacy organizations brought two actions in federal court claiming Wisconsin's voter ID law violates Section Two of the Voting Right Act ("VRA") and the Fourteenth Amendment. ${ }^{212}$ In that case, the federal judge found that Wisconsin's law does violate Section Two of the VRA by having a disproportionate impact on the voting rights of African-Americans and Latinos. ${ }^{213}$ The judge also found that the law violates the Fourteenth Amendment by imposing a substantial burden on the eligible voters who do not currently possess a photo ID. ${ }^{214}$ In determining that the law violated the Fourteenth Amendment, the court weighted the burden on the voter against the state interest and decided that the law's "burdens are not justified by the

\footnotetext{
${ }^{206}$ League of Women Voters of Wis. Educ. Network, Inc. v. Walker, 834 N.W.2d 393, 396 (Wis. Ct. App. 2013).

${ }^{207} \mathrm{Id}$.

${ }^{208}$ League of Women Voters of Wis. Educ. Network, Inc. v. Walker, 2012 WL 1020229, *2 (Wis. Ct. App. Mar. 28, 2012).

${ }^{209}$ League of Women Voters of Wis. Educ. Network, Inc., 834 N.W.2d at 396.

${ }^{210} \mathrm{Id}$.

${ }^{211}$ League of Women Voters of Wis. Educ. Network, Inc. v. Walker, 340 Wis. 2d 546 (2012).

${ }^{212}$ Frank v. Walker, 2014 WL 1775432, at *1 (E. D. Wis. Apr. 29, 2014).

${ }^{213}$ Id. At $* 1$.

${ }^{214}$ Id.
} 
state's interest in detecting and preventing in-person voter impersonation.”215 This decision was appealed to the Seventh Circuit U.S. Court of Appeals, which found that decision in Crawford v. Marion County Board of Elections "requires us to reject a constitutional challenge to Wisconsin's statute."216 The court stated that voter ID laws are "valid in every state-holding constant the burden each voter must bear to get a photo ID - or they are valid in no state. Functionally identical laws cannot be valid in Indiana and invalid in Wisconsin. . ..”217 The United State Supreme Court declined to hear an appeal, making the decision of the Seventh Circuit upholding the law final. ${ }^{218}$

As noted earlier, the Secretary of State of Kansas, Kris Kobach, phrased the issue best: the real question is not how many instances of voter fraud exist can be prevented by the voter photo ID laws, but rather, whether the number of instances of voter fraud could ever be larger than the margin of victory for any particular election. ${ }^{219}$ If the answer to that question is yes, then voter photo ID laws are necessary to ensure that a candidate gets elected properly. Elections with very small margins of victory are not unusual at both the local level and national levels. When the margin of victory is small and there is a public perception of voter fraud, then the public's faith is shaken for the candidate who is declared the winner and for laws he or she enacts.

In addition to the benefit of a more secure electoral system, voter photo ID laws have other positive effects. First, such laws encourage everyone to obtain a photo ID, which can then be used to allow people to do more than vote. People without a photo identification of some type live on the fringe of the society and cannot easily integrate into it. Without a photo ID, people are unable to do many things.

Without government-issued identification, entire families are trapped in limbo. The lack of ID can shut the doors to doctors' offices, banks, libraries, apartment rentals, charities — virtually anything you can think of. Even something as fundamental as walking into a bank to open an account or cash a paycheck becomes impossible. ${ }^{220}$

Obtaining a photo ID "would bring ... people currently living in the shadows

\footnotetext{
${ }^{215}$ Id. At $* 18$.

${ }^{216}$ Frank v. Walker, 768 F.3d 744 at 750 (7th Cir. 2014).

${ }^{217}$ Id.

${ }^{218}$ Lawrence Hurley, U.S. top court rejects challenge to Wisconsin voter ID law, REUTERS, http://www.reuters.com/article/2015/03/23/us-usa-court-electionidUSKBN0MJ1DZ201 50323 (last updated Mar. 23, 2015).

${ }^{219}$ Kobach, supra note 87.

${ }^{220}$ Bill De Blasio, Give ID Cards to All New Yorkers, New York DaiLy News, http://www. nydailynews.com/opinion/give-id-cards-new-yorkers-article-1.1344040 (last updated May 15, 2013).
} 
into mainstream society."221

Another related and positive development is the nurturing of a civicmindedness that can lead to greater participation in society. ${ }^{222}$ Alexis de Tocqueville made this observation in 1839 in Democracy in America. ${ }^{223} \mathrm{He}$ observed that jury duty-another form of "burden" imposed by citizenship in a free society - "rubs off the rust of self-interest by requiring persons to consider interests other than their own." 224 Similarly, contemporary social theories, such as "subsidiarity" advocated in Robert Bellah's classics Habits of the Heart ${ }^{225}$ and The Good Society, ${ }^{226}$ recognize the indispensability of citizen participation in society. ${ }^{227}$ If voter photo ID laws help bring citizens from the margins of society into active participation, our democratic society will be stronger and more inclusive.

\section{B. Identifying Portions of Foreign Voter Photo ID Laws Suitable for Use in the United States}

In the countries discussed in part IV above, all elections are run by the federal government — not by the states — as is the case with the United States. Because of federalism, the United States is unique in reserving to the states the power to conduct elections. ${ }^{228}$ Even so, there are lessons to be learned from foreign approaches. Those countries have long recognized the potential for voter fraud and the need for voter photo ID laws to prevent it. Voter photo ID laws are the norm when casting a ballot in each of these countries. ${ }^{229}$

However, for at least two reasons, some provisions of foreign methods for implementing voter photo ID laws are not suitable for use by states in the United States. First, the elections in these countries are administered by the federal government, while the U.S. Constitution requires elections in the

\footnotetext{
${ }^{221} I d$.

2221 Alexis De TocqueVille, Democracy in America, 192 (Alfred A. Knopf, Inc. 1972) $(1835,1840)$.

${ }^{223} \mathrm{Id}$.

${ }^{224} \mathrm{Id}$.

225 See generally RoBert N. BELlah , HABits OF THE HEART (1985).

${ }^{226}$ See generally ROBERT N. BELLAH, THE GOOD SOCIETy (1992).

227 Id. at 135-36. "Subsidiarity" describes a principle in which power is retained in the local government and the larger units of government serve as a support system for the local government in carrying out their tasks. This principle encourages citizen participation by making people "responsible for solutions for the whole rather than involving them simply as interested parties . . . when their private interests are threatened." Id.

228 U.S. Const. art. I, § 4, cl. 1.

229 See Constituicao Federal, supra note 152; Canada Elections Act, Part 9, Section 143 http://www.elections.ca/content.aspx?section=res\&dir=loi/fel/cea\&document=part09\&lang= e\#sec143; Household Registrations Act, LAWS AND REGULATIONS DATABASE OF THE REPUBLIC OF CHINA, http://law.moj.gov.tw/Eng/LawClass/LawAll.aspx?PCode=D0030006 (last updated May 25, 2011); ANGLOINFO, supra note 178; LÉGISLATIVES AsSEMBLÉE NATIONALE, supra note 180; ANGLOINFO, supra note 183.
} 
United States to be administered at the state level. ${ }^{230}$ This system allows each state to design and administer elections in ways best suited for particular, local circumstances. Provisions in foreign laws that allow the federal government to dictate particular methods of election administration are not appropriate for our states. Second, people of the United States have a history and culture of disapproving of power exerted by the federal government that is seen as too intrusive. ${ }^{231}$ Any attempts made by the federal government in the United States to register or track all the citizens, as with fingerprinting in Brazil, or the household registration system in Taiwan, would likely not receive public approval in the United States. Recognizing this disapproval of a federal registration system by United States citizens, United States Senator Rand Paul has introduced legislation to prohibit the issuance of a national identification card system, saying the national card "offends any reasonably basic concept of freedom.”232 Prior attempts to promote a national identification system in the United States also failed to garner any meaningful level of support in Congress by members of either party. ${ }^{233}$

While laws in other countries validate the concept and rationale for voter photo identification laws, the mechanisms for implementing a voter photo ID law must be consistent with American values. In this regard, the voter photo ID laws currently in place in Georgia, Indiana, Kansas, and Tennessee should serve as models for other states around the country. The voter photo ID laws enacted in each of these states have been upheld because they include mechanisms to minimize the burden on voters. The law, as designed by Pennsylvania, did not adequately minimize burdens and was therefore struck down. However, the laws in the four states discussed in this Note have measures built-in to safeguard against risk of disenfranchisement that would outweigh the benefits of requiring the photo ID. These safeguards were not built into Pennsylvania's law. Safeguards built into the laws of Georgia, Indiana, Kansas, and Tennessee exempt certain people, such as the exemption for people with a religious objection to being photographed. For people who do not fit within an exemption, these states' laws allow people to cast a provisional ballot if they are unable to show an acceptable ID at the polls. These voters are then permitted to go to a county election office at a

\footnotetext{
${ }^{230}$ U.S. Const. art. I, § 4, cl. 1.

231 The people's reaction to the recent scandal with the National Security Administration is a good example of this dislike for "power grabs" by the federal government. See John Walker, The More the American People Learn, the More They Disapprove of the NSA, FDL, http://fdlaction.firedoglake.com/2014/01/21/the-more-the-american-people-learn-the-morethey-disapprove-of-the-nsa/ (last updated Jan. 21, 2014).

232 Sen. Paul Introduces National ID Card Amendment, RAND PAUl United StATES SENATOR, http://www.paul.senate.gov/?p=press_release\&id=868 (last updated Jun. 20, 2013).

${ }^{233}$ Oppose Backdoor Attempts to Institute a National ID, AMERICAN CIVIL LiBERTIEs Union, https://www.aclu.org/oppose-backdoor-attempts-institute-national-id (last visited Mar. 10, 2014).
} 
later time to present their ID. A voter who does not have a photo ID also has the ability to vote absentee-by-mail. This ability further reduces the chance of disenfranchisement.

The most important reason the laws in these four states have been upheld is because each state has implemented effective methods to enable voters to obtain free photo identification cards. Since there are methods for low-income people to obtain a photo identification card for free, financial cost cannot be a basis for claiming disenfranchisement. The only hurdle to obtaining a photo ID is for the person to get to the appropriate office to obtain a card. This is a relatively low cost in comparison to a benefit of making elections more secure, especially given the various available transportation options. In addition, as discussed more fully in section V-A above, transportation is available from multiple providers.

Especially when implemented in combination, the factors enable courts to conclude that voter photo ID laws do not place an undue burden on the right to vote. Many of the state courts that have heard challenges to voter photo ID laws, and the United States Supreme Court, have found that those challenging the voter photo ID laws have been unable to point to any specific person or group of people who were precluded from voting because they could not obtain a photo ID, qualify for an exemption, or cast an absentee ballot. $^{234}$

\section{RECOMMENDATION}

The specter of voter fraud lessens citizens' trust in the election system, which in turn reduces citizen confidence in government. To combat this problem, states should implement a voter photo identification law. Based on our federalist system of government, where states administer elections, and our culture, which rejects a national identification card as too intrusive, the best option for states is to enact legislation to require voters to show some form of photo identification provided by the state or federal government.

People in the United States are required to show a photo ID for many reasons. Photo IDs are needed to make claims for Social Security benefits, to board airplanes, to buy alcohol, to get married, and for numerous other reasons, all of which are indisputably less important than deciding who will run our states and our country.

Requiring a voter to prove his or her identity before voting is neither a new idea nor one exclusive to the United States. Voter photo ID laws are in place in many democratic countries around the world and may be considered the norm. Requiring a person to show a photo ID when engaged in an activity as important and influential as voting is logical, reasonable, and beneficial to the preservation of democratic ideals.

${ }^{234}$ Crawford v. Marion Cnty. Election Bd., 553 U.S. at 201. 


\section{CONCLUSION}

To maintain the integrity of elections, every state in the United States should enact a voter photo identification law. The main benefits of these laws-election integrity and faith in the government-outweigh the small costs involved.

There are many reasons to support voter photo ID laws. The primary reason to support these laws is to maintain the integrity of the government. Another reason is that they are the norm in other democratic counties. Voter photo ID laws are almost universally accepted by democratic countries the United States respects and often views as models. States in the United States are beginning to see the same issues, have the same concerns, and seek to promote the same values already recognized and addressed in other countries. Voter photo ID laws are also widely accepted by many citizens of the United States.

Based on our republican form of government, the voter photo ID law is the most effective choice for the states in our country. Nothing is more important in our society than having faith in our government, and people cannot have faith in government if they do not have faith in elections.

\section{EPILOGUE}

Political cartoons often provide concise and insightful analysis of legal and social issues. The cartoon reproduced below captures some of the points made in this note. ${ }^{235}$

235 Gary Varvel, available at http://s292.photobucket.com/user/haulwilliams/media/garyvarvel-voter-id.jpg.html (last visited Feb. 15, 2014). 

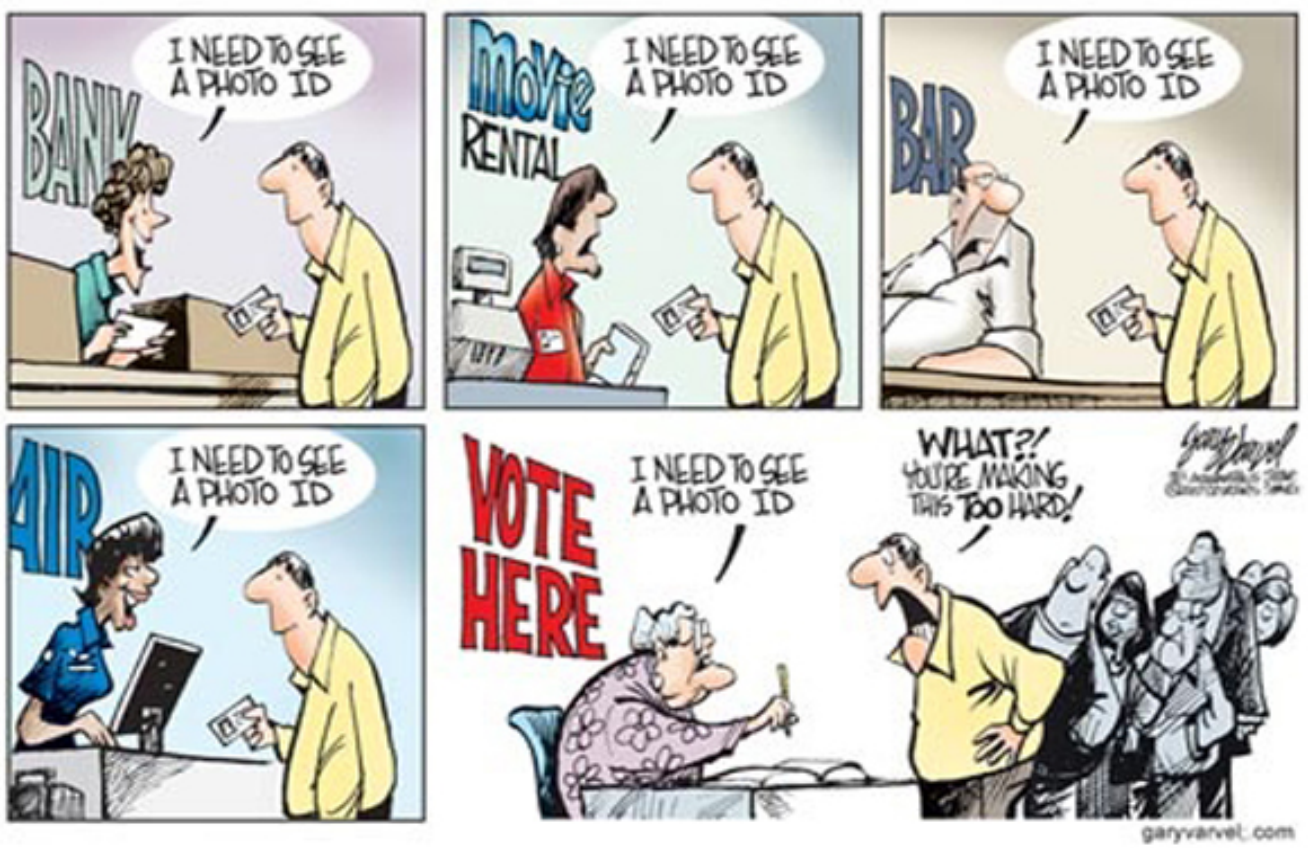